\title{
HEAVY METAL POLLUTION OF AGRICULTURAL SOILS AND VEGETABLES OF BHAKTAPUR DISTRICT, NEPAL
}

\author{
Sadhana Pradhanang Kayastha* \\ *Central Department of Environmental Science, Tribhuvan University, Kirtipur, Kathmandu, Nepal.
}

\begin{abstract}
The aim of this study was carried out to assess heavy metals $(\mathrm{Cu}, \mathrm{Zn}, \mathrm{Pb}, \mathrm{Cd}$,) in soils as well as vegetables of respective place of the Bhakatpur District (Manohara, Nagadesh, Bode, Hanumanghat, Sipadol, Tathali and Gundu). The leafy vegetables under this study were Spinach, Cauliflower, Carrot, Cabbage and Broad leaf mustard. The results showed that the concentration of heavy metals in the plants and soils from the Bhakatpur was proportional in the order $\mathrm{Zn}>\mathrm{Cu}>\mathrm{Pb}>\mathrm{Cd}$. Spinach showed the extremely high accumulation tendency towards the heavy metals compare to other vegetables. The geo-accumulation class $\left(\mathrm{I}_{\text {geo }}\right)$ indicates that the agricultural soil of Hanumanghat, Manohara, Nagadesh and Bode are moderately contaminated of $\mathrm{Cd}$.
\end{abstract}

Keywords: Heavy metals; Soils; Vegetables; Accumulation.

\section{INTRODUCTION}

Soil is not only the key nutrient-bearing environment for plant life (Heike, 2004) but also a supplier of many pollutants to plants because plants can uptake toxic substances through their roots from soils (Youssef and Chino, 1991). Heavy metals are extremely persistent in the environment; they are non-biodegradable and nonthermo degradable and thus readily accumulate to toxic levels. Heavy metals can accumulate in the soil at toxic levels due to the long term application of wastewater (Bohn et al., 1985). Monitoring of the contamination of soil with heavy metals is of interest due to their influence on ground water and surface water and also on plants, animals and humans. Increase of human population as well as proportionate increase in the requirement of food is one of the challenges in Nepal. The existing farming practice explores high yielding varieties and intensive cropping pattern that required higher use of external inputs such as irrigation, pesticides use and so on for more yields. It is important to understand the status and extent of soil contamination with heavy metals to make sustainable management strategies for agricultural soils. The main sources of heavy metals in agricultural soils are due to activities such as irrigation using wastewater, agricultural fertilizers, pesticides, organic manure, disposal of urban and industrial wastes and atmospheric pollution from motor vehicles and the combustion of fossil fuels (Nicholson et al., 2003; Zhang, 2006). Toxic heavy metals entering the ecosystem may lead to geoaccumulation, bio-accumulation and bio-magnifications.
They get accumulated in time in soils and plants and would have a negative influence on physiological activities of plants (e.g. photosynthesis, gaseous exchange and nutrient absorption) determining the reductions in plant growth, dry matter accumulation and yield (Suciu et al., 2008). Thus, excessive accumulation of heavy metals in agricultural soils not only results in environmental contamination, but also elevates heavy metal uptake by crops which also affects food quality and safety. Pollutants from agrochemicals sources include fertilisers, manure and pesticides. There is increasing trend of neurological problems in Nepal. One of the causes of increased neurological problem is due to the consumption of food and vegetables contaminated with heavy metal (Duruibe et al., 2007). Different types of heavy metals are basically released from pesticide, fertilizer and use of industrial effluents for irrigation in Nepal. The use of pesticides has been increasing rapidly in recent years. Total amount of pesticide is used 347 tons per year in Nepal, which consists of $68 \%$ fungicide, $11 \%$ rodenticide, $17 \%$ insecticide and $4 \%$ herbicide (CBS, 2006). All these pesticides contain different concentration of heavy metals which is available in considerable amount in the soil once they are being used. The available heavy metals in the soil get accumulated in the vegetation by the natural process of bioaccumulation (Chao et al., 2007). The main pollution effect caused by fertilizers, pesticides and chicken manure is the introduction of heavy metals into the soil (Mirsal, 2004). These are the introduction of the heavy metals (As,

Author for Correspondence: Sadhana Pradhanang Kayastha, Central Department of Environmental Science, Tribhuvan University, Kirtipur, Kathmandu, Nepal. E-mail: sadhana.pradhanang@gmail.com. 
$\mathrm{Cd}, \mathrm{Pb}, \mathrm{Mn}$ and $\mathrm{Zn}$ ) by some phosphate fertilizer and soil contamination with $\mathrm{Zn}$, As and $\mathrm{Cu}$ when chicken or pig manures are used (Mirsal, 2004). The use of agrochemical in agriculture has been steadily increasing in the last couple of years in the Nepal. Some of the heavy metals are essential for plant metabolism such as $\mathrm{Cu}, \mathrm{Fe}, \mathrm{Mn}, \mathrm{Si}, \mathrm{Mo}, \mathrm{Co}$, Se and Zn. These metals show that not only heavy metals in soil cause environmental problems but also deficiencies of heavy metals may lead to imbalance in the soil-plant-animal system. Soilto-plant transfer of heavy metals is the major pathway of human exposure to soil contamination. The plant uptake of chemical species in soil solution is also dependent on a number of plant factors. These include: physical processes such as root intrusion, water, and ion fluxes and their relationship to the kinetics of metal solubilisation in soils; biological parameters, including kinetics of membrane transport, ion interactions, and metabolic fate of absorbed ions (Cataldo and Wildung, 1978). Bhakatpur district is one of the most important areas for vegetables production. Bhaktapur is one of the supply centres for fresh vegetables to the Kathmandu markets. Vegetables cultivated in wastewater-irrigated, application of chicken manure and chemical fertilizers and pesticides which reported to be a source of metals in food (Modaihsh et al., 2004). Thus long term accumulation of these elements in soil might have been passed to the vegetables through a root uptake. The toxic metals concentration can reduce soil fertility, can increase input to food chain, which leads to accumulate toxic metals in food stuffs, and to cause potential health risks to the consumers (Khan et al ., 2008).

A number of studies have shown heavy metals as important contaminants of vegetables (Singh and Kumar, 2006). Hence, the objective of this study is to analyze the concentration of heavy metals $(\mathrm{Cu}, \mathrm{Zn}, \mathrm{Cd}$ and $\mathrm{Pb}$ ) in agricultural soils as well as in the vegetations of respective places. The leafy vegetables under this study were Spinach, Cauliflower, Carrot, Cabbage and Broad leaf mustard.

\section{MATERIALS AND METHODS}

\section{Study area}

Bhaktapur district is one of the smallest districts of Nepal with only 138.46 square kilometers of land and 225 thousand inhabitants. Agriculture is prime occupation for Bhaktapur people. The vegetable farms were located in the Bhaktapur District that is Madhypur Thimi (Manohara, Nagadesh and Bode), Hanumanghat, Sipadol, Tathali and Gundu (Fig. 1). Manohara is one of the most important areas for vegetables production.

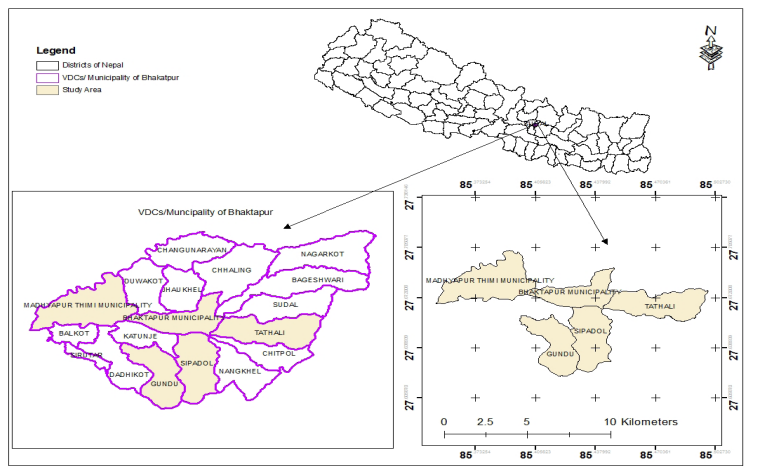

Figure 1: Sampling locations of the study area.

\section{Sampling}

\section{Soil Sampling}

Samples were collected from Madhypur Thimi (Manohara, Nagadesh and Bode), Hanumanghat, Sipadol, Tathali and Gundu in December 2012. Soil Samples were collected manually with the help of metallic core cutter of $10-15 \mathrm{~cm}$ diameter. Composite surface soil $(0-20 \mathrm{~cm})$ samples (from a bulk soil made up of 5 different soil samples per farm) of the vegetables farm were collected separately and properly labeled and samples were stored in plastic bag with zip lock.

\section{Analytical procedure}

Once the samples were in the laboratory, soil samples were air-dried at ambient laboratory temperature. The air-dried soil samples were crushed to pass a 2-mm mesh sieve. The samples were dried and powdered in a pestle and mortar prior to analysis.

The samples were then stored at $4^{\circ} \mathrm{C}$ until required for analysis. One gm of air dried powdered sample was added

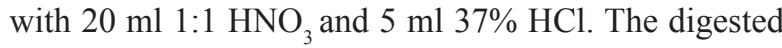
samples were heated at $80^{\circ} \mathrm{C}$ on water bath till dryness and added with de-ionized water. Digested samples were then filtered and subsequently diluted with de-ionized water. $\mathrm{Zn}, \mathrm{Cu}, \mathrm{Pb}$ and $\mathrm{Cd}$ determined by acetylene-air flame atomic absorption Spectrophotometry (AA- 6000, Shimadzu, serial no A30534, Shimazu, Corp, 00740).

\section{Vegetables Sampling}

All the vegetables were collected from respective sites where soil samples were collected. Three replicates at each vegetable were collected directly from the field in zip lock polythene bags. Plants collected at each site were carefully and repeatedly hand-washed and rinsed in deionised water to eliminate the dust that had accumulated on the aerial parts. Vegetable were weighed after washing with de-ionized water and blotting dry with tissue paper. Plant parts were then oven-dried at $60^{\circ} \mathrm{C}$ for 72 hours weighed and ground. The samples were dried and powdered in a pestle and mortar prior to analysis. One gram of oven dried powered sample mixed with $15 \mathrm{ml}$ of tri- acid mixture $(70 \%$ high purity $\mathrm{HNO}_{3}, 65 \% \mathrm{HClO}_{4}$ and $70 \% \mathrm{H}_{2} \mathrm{SO}_{4}$ in 5:1:1 ratio). The mixture was then digested at $80^{\circ} \mathrm{C}$ till the solution became transparent (Allen, et al., 1986). The solution 
was filtered and diluted to $50 \mathrm{ml}$ using deionized water and analyzed for concentrations of $\mathrm{Cu}, \mathrm{Zn}, \mathrm{Pb}$ and $\mathrm{Pb}$ using an atomic absorption spectrophotometer. Standard solutions were prepared from stock solution (Merck, Germany) of heavy metals. The AAS was calibrated for all the metals by running different concentrations of standard solutions. Average values of three replicates were taken for each determination. All glassware was acid-washed using 10\% nitric acid before use.

\section{RESULT AND DISCUSSION}

Heavy metal concentration in the soil samples collected from agricultural lands of Bhakatpur district, Nepal (Manohara, Nagadesh, Bode, Hanumanghat, Sipadol, Tathali and Gundu). The ranges in the content of metals in soil samples were $13.76-60.56 \mathrm{mg} / \mathrm{kg}$ for $\mathrm{Cu}, 58.67-180.62 \mathrm{mg} / \mathrm{kg}$ for $\mathrm{Zn}, 4.67-67.43 \mathrm{mg} / \mathrm{kg}$ for $\mathrm{Pb}, 0.08-1.52 \mathrm{mg} / \mathrm{kg}$ for $\mathrm{Cd}$, Below detection limit ( BDL) to $0.60 \mathrm{mg} / \mathrm{kg}$ (Table 1). The results showed an irregular pattern of the heavy metal availability in soil samples. $\mathrm{Cu}, \mathrm{Zn}, \mathrm{Pb}$ and $\mathrm{Cd}$ concentration was noticed to be higher in Hanumanghat compared to other sites. In this study area, soil contamination with metals could be mainly due to waste water irrigation, application of sludge, chicken manure, diammonium phosphate (DAP), urea and pesticides in the farm land.

\section{Accumulation of heavy metals in vegetables}

Concentration of trace heavy metals in vegetables plants depends upon the soil of the cultivated area, the atmospheric condition and the irrigated water. The concentrations of heavy metals in edible parts of vegetables like spinach, cauliflower, carrot, cabbage and broad leaf mustard from agricultural soils: Manohara, Nagadesh, Bode, Hanumanghat, Sipadol, Tathali and Gundu which irrigated with freshwater and untreated sewage waters. Heavy metal concentrations varied among different vegetables (Tables 2), which may be attributed to differential absorption capacity of vegetables for different heavy metals (Singh et al., 2010). The copper, concentration in the spinach was found to be 7.8 . to $17.20 \mathrm{mg} / \mathrm{kg}, 7.90$ to $14.40,5.5$ to $12.5,12.60$ to 16.70 and 4.9 to 13.50 in Manohara, Nagadesh, Bode, Hanumanghat, Sipadol, Tathali and Gundu, respectively (Table 2). The mean concentration of $\mathrm{Zn}$ in spinach, cauliflower, carrot, cabbage and broad leaf mustard, respectively, varied from 75.89 to140.61, 59.65 to $88.45,21.46$ to $55.17,56.60$ to $120.54,27.56$ to $60.73(\mathrm{mg} / \mathrm{kg})$. Present study reveals that $\mathrm{Pb}$ varied from 0.20 to $3.20 \mathrm{mg} / \mathrm{kg}$. The highest concentration of $\mathrm{Pb}$ was found in leafy part of spinach $(3.20 \mathrm{mg} / \mathrm{kg})$ in Manohara while lowest concentration $0.20 \mathrm{mg} / \mathrm{kg}$ was recorded in broad leaf mustard (Tahathali). The highest concentration of $\mathrm{Cd}(0.61 \mathrm{mg} / \mathrm{kg})$ was observed in spinach (Hanumanghat) and lowest concentration BDL was found in cabbage (Tathali).

The concentration of heavy metals in the soil and vegetable follows the order: $\mathrm{Zn}>\mathrm{Cu}>\mathrm{Pb}>\mathrm{Cd}$. The copper concentration levels were slightly high in most of the vegetables. It was high in edible part of cabbage and spinach compare to other plants, especially from Manohara and Hanumanghat and Nagadesh sampling sites. Some of the sites showed higher $\mathrm{Cu}$ concentrations which may be a result of vegetables absorption of $\mathrm{Cu}$ through the use of $\mathrm{Cu}$ laden fungicide sprays commonly used on vegetable farms. Spinach and cabbage growing in contamination soil in $\mathrm{Cu}$ with a considerable risk of transfer towards the plants. Soil to plant transfer factor is one of the key components of human exposure to metals through the food chain. The food chain is one of the most important pathways cause human health risks. The acceptable limit for human consumption of $\mathrm{Cu}$ is $10 \mathrm{mg} / \mathrm{kg}$ (Nair et al., 1997). $\mathrm{Cu}$ is trace element that is essential for human health, when $\mathrm{Cu}$ exceeds its safe level concentration, it can cause health problem such as anaemia, liver and kidney damage and stomach and intestinal irritation (Zhang and Wong, 2007). By comparison with present study, Krishna and Govil (2007) also reported higher concentration of $\mathrm{Cu}$ (137.7 $\mathrm{mg} / \mathrm{kg}$ ) in the soil from industrial areas of Surat, Western India. $\mathrm{Zn}$ concentration has the highest value in the soil $(180.62 \mathrm{mg} / \mathrm{kg}$ ) while the concentration of $\mathrm{Zn}$ is also highest in the spinach plant $(140.61 \mathrm{mg} / \mathrm{kg})$. High concentration levels of zinc can damage the pancreas and disturb the protein metabolism and cause arteriosclerosis (Zaidan et al., 2013). Maximum Zn tolerance for human health has been established for edible parts of vegetables is $100 \mathrm{mg} / \mathrm{kg}$ by FAO/WHO (2001). In this study, the concentration of $\mathrm{Zn}$ in vegetables was as fallow: spinach $>$ cabbage $>$ cauliflower $>$ broad leaf mustard $>$ carrot. The zinc concentration level in broad leaf mustard and carrot (some of sampling sites) was found to be lower than the permissible value $(100 \mathrm{mg} /$ $\mathrm{kg}$ ) in food proposed by FAO/WHO (2001). Vegetables that growing on heavy metal contaminated soils can accumulate high concentrations of zinc to cause serious health risk to consumers. The high concentration of zinc in soil and vegetable could be due to the use of chicken manure, zinc in fertilizers and metal based pesticides. Sharma et al. (2007; 2009) also reported that the concentration of $\mathrm{Zn}$ has found to be $43.56 \mathrm{mg} /$ $\mathrm{kg}$ and $109.09 \mathrm{mg} / \mathrm{kg}$, in the vegetables, respectively. The average daily intake of Zinc is $7-16.3 \mathrm{mg} /$ day; the recommended dietary allowance for it is $15 \mathrm{mg} \mathrm{Zn/day}$ for men and $12 \mathrm{mg} \mathrm{Zn/day} \mathrm{for} \mathrm{women} \mathrm{(ATSDR} \mathrm{1994a).}$

The concentration of $\mathrm{Pb}$ is least in the soil (Manohara) while in the Spinach grown (Manohara) on it has more concentrations. These variations of heavy metal in soil and plant are due to differences in the sources of the metal. Some of the metals are already present in the plant and the soil will contribute to the metal bioavailability. The global baseline level of $\mathrm{Pb}$ in uncontaminated surface soils is $20 \mathrm{mg} / \mathrm{kg}$ (Kabata- Pendias and Pendias, 2000). The mean $\mathrm{Pb}$ concentration in Florida soils is 
Table 1: Heavy metals concentration (mean value in $\mathrm{mg} / \mathrm{kg}$ ) in soils at different field location.

\begin{tabular}{|c|c|c|c|c|c|}
\hline Soil $(n=5)$ & Location & $\mathbf{C u}$ & Zn & $\mathbf{P b}$ & Cd \\
\hline \multirow[t]{7}{*}{ Spinach } & Manohara & 30.21 & 145.56 & 4.67 & 0.56 \\
\hline & Nagadesh & 45.41 & 142.06 & 48.52 & 0.85 \\
\hline & Bode & 13.76 & 128.45 & 38.18 & 0.78 \\
\hline & Hanumanghat & 55.45 & 180.62 & 60.54 & 1.20 \\
\hline & Sipadol & 23.42 & 98.96 & 27.80 & 0.76 \\
\hline & Tathali & 18.54 & 89.98 & 37.80 & 0.62 \\
\hline & Gundu & 15.34 & 120.34 & 23.42 & 0.78 \\
\hline \multirow[t]{7}{*}{ Cauliflower } & Manohara & 31.23 & 140.31 & 45.32 & 0.71 \\
\hline & Nagadesh & 42.34 & 120.23 & 56.45 & 0.55 \\
\hline & Bode & 28.43 & 99.56 & 45.34 & 0.98 \\
\hline & Hanumanghat & 60.56 & 143.34 & 66.45 & 1.07 \\
\hline & Sipadol & 47.34 & 79.67 & 41.4 & 0.52 \\
\hline & Tathali & 32.2 & 67.81 & 50.34 & 0.64 \\
\hline & Gundu & 17.32 & 129.32 & 23.31 & 0.79 \\
\hline \multirow[t]{7}{*}{ Carrot } & Manohara & 33.56 & 134.50 & 48.90 & 1.06 \\
\hline & Nagadesh & 55.34 & 130.45 & 46.32 & 1.02 \\
\hline & Bode & 25.45 & 120.34 & 23.42 & 0.87 \\
\hline & Hanumanghat & 41.32 & 98.43 & 45.30 & 0.98 \\
\hline & Sipadol & 48.42 & 99.03 & 34.83 & 0.83 \\
\hline & Tathali & 35.4 & 67.56 & 23.67 & 0.47 \\
\hline & Gundu & 24.45 & 87.45 & 16.34 & 0.68 \\
\hline \multirow[t]{7}{*}{ Cabbage } & Manohara & 56.36 & 166.45 & 30.45 & 0.98 \\
\hline & Nagadesh & 45.45 & 134.50 & 22.45 & 0.32 \\
\hline & Bode & 30.76 & 123.34 & 19.32 & 0.13 \\
\hline & Hanumanghat & 59.32 & 127.32 & 50.25 & 0.73 \\
\hline & Sipadol & 46.34 & 88.34 & 20.45 & 0.17 \\
\hline & Tathali & 36.32 & 150.34 & 32.45 & 0.08 \\
\hline & Gundu & 49.30 & 124.78 & 25.78 & 0.30 \\
\hline \multirow[t]{7}{*}{ Broad leaf } & Manohara & 32.34 & 131.34 & 44.32 & 0.65 \\
\hline & Nagadesh & 34.45 & 125.23 & 24.34 & 1.03 \\
\hline & Bode & 22.31 & 58.67 & 27.45 & 0.88 \\
\hline & Hanumanghat & 56.01 & 120.34 & 56.34 & 1.52 \\
\hline & Sipadol & 34.34 & 119.32 & 67.43 & 0.60 \\
\hline & Tathali & 53.07 & 132.04 & 25.34 & 0.26 \\
\hline & Gundu & 23.45 & 120.34 & 30.45 & 0.48 \\
\hline
\end{tabular}


Table 2: Heavy metals concentration (mean value in $\mathrm{mg} / \mathrm{kg}$ ) in vegetables $(\mathrm{n}=5)$ at different field locations.

\begin{tabular}{|c|c|c|c|c|c|}
\hline Vegetables & Location & $\mathrm{Cu}$ & Zn & $\mathbf{P b}$ & Cd \\
\hline \multirow[t]{7}{*}{ Spinach } & Manohara & 15.51 & 100.48 & 3.20 & 0.24 \\
\hline & Nagadesh & 14.80 & 98.52 & 2.56 & 0.17 \\
\hline & Bode & 12.40 & 86.23 & 1.65 & 0.14 \\
\hline & Hanumanghat & 17.20 & 140.61 & 2.82 & 0.61 \\
\hline & Sipadol & 7.80 & 120.50 & 1.24 & 0.25 \\
\hline & Tathali & 10.45 & 99.42 & 0.52 & 0.12 \\
\hline & Gundu & 12.56 & 75.89 & 0.87 & 0.08 \\
\hline \multirow[t]{7}{*}{ Cauliflower } & Manohara & 10.3 & 60.7 & 2.38 & 0.20 \\
\hline & Nagadesh & 12.3 & 87.30 & 1.52 & 0.12 \\
\hline & Bode & 9.30 & 67.50 & 1.40 & 0.04 \\
\hline & Hanumanghat & 14.40 & 70.32 & 2.23 & 0.34 \\
\hline & Sipadol & 8.40 & 59.65 & 1.52 & 0.20 \\
\hline & Tathali & 7.90 & 62.17 & 0.80 & 0.10 \\
\hline & Gundu & 12.34 & 88.45 & 0.78 & 0.11 \\
\hline \multirow[t]{7}{*}{ Carrot } & Manohara & 12.5 & 35.23 & 1.42 & 0.16 \\
\hline & Nagadesh & 8.6 & 45.19 & 1.80 & 0.11 \\
\hline & Bode & 4.5 & 37.13 & 0.33 & 0.13 \\
\hline & Hanumanghat & 4.8 & 55.17 & 2.92 & 0.42 \\
\hline & Sipadol & 6.0 & 34.80 & 0.59 & 0.18 \\
\hline & Tathali & 5.51 & 21.46 & 0.42 & 0.20 \\
\hline & Gundu & 6.40 & 23.34 & 0.67 & 0.10 \\
\hline \multirow[t]{7}{*}{ Cabbage } & Manohara & 13.7 & 120.54 & 2.20 & 0.24 \\
\hline & Nagadesh & 16.3 & 105.72 & 1.82 & 0.14 \\
\hline & Bode & 14.8 & 66.45 & 0.33 & 0.09 \\
\hline & Hanumanghat & 16.7 & 87.73 & 2.38 & 0.48 \\
\hline & Sipadol & 15.3 & 56.60 & 1.40 & 0.06 \\
\hline & Tathali & 12.6 & 76.93 & 0.92 & 0.18 \\
\hline & Gundu & 15.54 & 63.23 & 0.28 & BDL \\
\hline \multirow[t]{7}{*}{ Broad leaf Mustard } & Manohara & 9.8 & 56.26 & 1.97 & 0.21 \\
\hline & Nagadesh & 4.92 & 30.88 & 1.84 & 0.17 \\
\hline & Bode & 13.50 & 60.73 & 0.60 & 0.13 \\
\hline & Hanumanghat & 12.14 & 55.16 & 2.71 & 0.39 \\
\hline & Sipadol & 8.80 & 56.19 & 0.80 & 0.12 \\
\hline & Tathali & 10.7 & 67.9 & 0.20 & 0.11 \\
\hline & Gundu & 6.45 & 27.56 & 0.42 & 0.08 \\
\hline
\end{tabular}

Table 3: Correlation coefficient between the concentration of heavy metals in soil and edible part of vegetables.

\begin{tabular}{llllll}
\hline SN & Variables & \multicolumn{3}{c}{ Heavy metals } \\
& & $\mathbf{C u}$ & $\mathbf{Z n}$ & $\mathbf{P b}$ & $\mathbf{C d}$ \\
\hline 1. & Spinach and soil & $0.77^{*}$ & 0.43 & 0.04 & $0.77^{*}$ \\
2. & Cauliflower and soil & 0.33 & 0.42 & 0.55 & 0.26 \\
3. & Carrot and soil & 0.15 & 0.51 & 0.75 & 0.15 \\
4. & Cabbage and soil & 0.17 & $0.77^{*}$ & 0.57 & 0.63 \\
5. & Broad leaf mustard and soil & 0.27 & -0.20 & 0.38 & $0.85^{*}$ \\
\hline
\end{tabular}

(*significant at $\mathrm{P}=0.05)$ 
Table 4: Ratio between the concentration of heavy metals in edible part of vegetables and soil.

\begin{tabular}{llllll}
\hline \multirow{2}{*}{ SN } & \multirow{2}{*}{ Variables } & \multicolumn{4}{c}{ Heavy metals } \\
& & $\mathbf{C u}$ & $\mathbf{Z n}$ & $\mathbf{P b}$ & $\mathbf{C d}$ \\
\hline & & & & & \\
1. & Spinach and soil & 0.45 & 0.71 & 0.05 & 0.29 \\
2. & Cauliflower and soil & 0.29 & 0.64 & 0.03 & 0.21 \\
3. & Carrot and soil & 0.18 & 0.34 & 0.03 & 0.22 \\
4. & Cabbage and soil & 0.34 & 0.63 & 0.05 & 0.57 \\
5. & Broad leaf mustard & 0.26 & 0.44 & 0.03 & 0.22 \\
& and soil & & & & \\
\hline
\end{tabular}

Table 5: The geo-accumulation index consists of seven grades.

Igeo value I geo class Designation of soil quality

\begin{tabular}{lll}
\hline$>5$ & 6 & Extremely \\
$4-5$ & 5 & strongly to extremely contaminated \\
$3-4$ & 4 & strongly contaminated \\
$2-3$ & 3 & moderately to strongly contaminated \\
$1-2$ & 2 & moderately contaminated \\
$0-1$ & 1 & uncontaminated to moderately contaminated \\
0 & 0 & Uncontaminated \\
\hline
\end{tabular}

$77 \mathrm{mg} / \mathrm{kg}$ (Chen et al., 1999). Present study showed that most of vegetables, lead concentration is slightly higher than permitted level, so they are not suitable for consumption. Singh et al. (2004) have reported 3-15 fold higher concentration of $\mathrm{Pb}$ in wastewater irrigated area of Kanpur and Varanasi as compared to those reported in the present study. A maximum $\mathrm{Pb}$ limit for human health has been established for edible parts of crops by World Health Organization (WHO) standardises $0.3 \mathrm{mg} /$ $\mathrm{kg}(\mathrm{FAO} / \mathrm{WHO}, 2001)$ but this limit in China is $0.2 \mathrm{mg} /$ $\mathrm{kg}$ (Chinese Department of Preventive Medicine, 1995).

Cadmium is a trace element that is ubiquitous in soil. Cadmium is one of the most toxic heavy metals due to its high mobility and the small concentration at which its effects on crops begin to show ( Singh, 2010; Arora, 2008). As results obtained on $\mathrm{Cd}$, in the edible part of the plants absorbed a significant amount of $\mathrm{Cd}$ higher than in natural plant $(0.02-1.2 \mathrm{mg} / \mathrm{kg})$. Application of pesticides and phosphate fertilizers leads to dispersion of Cd (Alloway, 1995). It presents a serious hazard to public health and is a threat to most life forms (Breakman et al., 1997). WHO standards for $\mathrm{Cd}$ in vegetables are $0.1 \mathrm{mg} / \mathrm{kg}(\mathrm{FAO} / \mathrm{WHO}, 2001)$. Metal trace elements, including $\mathrm{Cd}$, cause severe damage at each level in living organisms, from populations and communities to cell elements (Schutzendubel et al., 2001). ). In this study, Cd has been found all the sampling sites (Table 1), it could be due to use of chicken manure, phosphate fertilizer and metals based pesticides.

In all the cases correlation coefficient between the concentration of heavy metals in soil and edible parts of vegetables was found to be positive (except for concentration of $\mathrm{Zn}$ content in broad leaved mustard and soil). The correlation between the concentration of $\mathrm{Cd}$ in soil and Spinach, $\mathrm{Zn}$ in soil and cabbage and, $\mathrm{Cd}$ in soil and broad leaved mustard was found to be significant at $\mathrm{P}=0.05$ (Table 3). It seems that leafy vegetables (spinach, broad leaved mustard), has the better absorption capacity to heavy metal $\mathrm{Cd}$.

Direct proportionality relationships were established between the heavy metals mobile forms content from soils and the edible part of vegetables. Of the heavy metals assessed $\mathrm{Cu}$ and $\mathrm{Zn}$ are required by organisms at some level and become toxic at some higher levels of exposure. Since these metals are required in minimum amounts for the plants, the ratio between the concentration of heavy metals in edible part of vegetables and soil was also found higher than $\mathrm{Pb}$ and $\mathrm{Cd}$ (Table 4). $\mathrm{Pb}$ and $\mathrm{Cd}$ are non-essential elements, are toxic, and not required by organisms at any level (Singh et al. 2010).

\section{Contamination degree based on Geo-accumulation Index ( $\left.\mathbf{I}_{\mathrm{geo}}\right)$}

Geo-accumulation Index ( $\left.\mathrm{I}_{\mathrm{geo}}\right)$ method was used to calculate the metal contamination levels for the soil samples from Manohara, Nagadesh, Bode, Hanumanghat, Sipadol, Tathali and Gundu. Index of Geo-accumulation (Igeo) has been used widely to evaluate the degree of metal contamination or pollution in soils (Tijani and Onodera, 2009). The method assesses the degree of metal pollution in terms of seven enrichment classes based on the increasing numerical values of the index (Table 5). This index is calculated as:

$\mathrm{I}_{\text {geo }}=\log 2 \mathrm{C}_{\mathrm{n}} / 1.5 \mathrm{~B}_{\mathrm{n}}$

where $\mathrm{C}_{\mathrm{n}}$ is the concentration of the element in the enriched samples and $B_{n}$ is the background or pristine value of the elements (Turekian and Wedepohl, 1961).

The geo-accumulation class for the soil varies from metal to metal and place to place. $\mathrm{Cu}$, and $\mathrm{Pb}$, appears to be the least contaminated elements in all the agricultural soil, while $\mathrm{Zn}$ shows uncontaminated to moderately. $\mathrm{Cd}$ shows the highest Igeo values for $\mathrm{Cd}$ (1.42) in Hanumanghat, Manohara (1.24) Nagadesh (1.18) and Bode (1.12) agricultural soil. This indicates that the agricultural soil of Hanumanghat, Manohara, Nagadesh and Bode are moderately contaminated of $\mathrm{Cd}$. Based on the classification system proposed for Igeo factors, Bhakatpur district (Manohara, Nagadesh, Bode, Sipadol, Tathali and Gundu) are classed on average as uncontaminated to moderately contaminate.

\section{CONCLUSION}

The present study has generated data on heavy metal concentration in soil and vegetables from Bhakatpur District. The soil is a long term sink for the group of potentially toxic elements often referred to as heavy metals, including zinc, copper, lead, cadmium, arsenic and mercury. These metals are usually small plant 
uptake compared to the total quantities entering the soil from different sources. The high contamination of heavy metals found in soil and vegetables which were closely related to the pollutants in irrigation water, agricultural soil fertilizers, dusts. The mean concentration of $\mathrm{Zn}$ was found highest in all vegetables tested followed by that of $\mathrm{Cu}, \mathrm{Pb}$, and $\mathrm{Cd}$, the same relation was found with vegetables. Waste water irrigated vegetables in Hanumanghat as shown higher accumulation of zinc, copper, lead and cadmium compared to the fresh waterirrigated in other study sites. Spinach indicated the highest metal absorption capacity compare to other vegetables studied. The geoaccumulation indix (Igeo) was calculated and used in agricultural soil samples of Bhaktapur district which presents the geo-accumulation index for the quantification of heavy metal accumulation in the soil. The Igeo factor is not readily comparable due to the nature of Igeo calculation which involves a log function and a background multiplication of 1.5. The geoaccumulation indix (Igeo) of the soil ranged from uncontaminated to moderately contaminate with respect to analysed metals. It is therefore suggested that regular monitoring of heavy metals in soil and vegetables should be performed and alternative options should be carried out in order to prevent excessive accumulation of these heavy metals in the human food chain and ultimately cause risk to human health. Replication of such type of study should be performed where excessive vegetables are produced.

\section{ACKNOWLEDGMENT}

The author is highly thankful to University Grants Commission, Nepal for a research grant.

\section{REFERENCES}

1. Agency for Toxic Substances and Disease Registry (ATSDR).1994a. Toxicological Profile for Zinc and Cobalt. US Department of Health and Human Services, Public Health Service. 205-88- 608

2. Alloway, B.J., 1995. Heavy Metals in Soils, 2nd ed. Blackie, Academic \& Professional Publishers, London.

3. Allen, S.E., Grimshaw, H.M., Rowland, A.P., 1986. Chemical analysis. In: Moore, P.D., Chapman, S.B. (Eds.), Methods in Plant Ecology. Blackwell, Scientific Publication, Oxford, London.

4. Arora,M., Kiran,B., Rani,S., Rani, A., Kaur, B., Mittal, N., 2008. Heavy metalaccumulation in vegetables irrigated with water from different sources. Food Chemistry. 111 : 811-815.

5. Bohn, H.L., McNeal. B.L., O’Connor, A.G. 1985. Soil Chemistry second edition. Wiley-Inter Science Publication, New York, USA.

6. Breakman, B., Raes, H., Van, Hoye., D. 1997.Heavy-metal toxicity in an insect cell line.Effects of cadmium chloride, mercuric chloride and methylmercuric chloride on cell viability and proliferation in Aedesalbopictus cell. Cell Biology Toxicology. 13: 389-397

7. Cataldo, D.A., Wildung, R. E., 1978. Soil Plant factors influencing the accumulation of Heavy Metals by Plants. Environmental Health Perspectives. 27: 149-159.

8. CBS, 2006.Agriculture Census Nepal 2001/02. National Planning Commission Secretariat, Central Bureau of Statistics, Kathmandu,
Nepal.

9. Chao, W., Xiao-chen, L., Li-min, Z., Pei-fang, W., Zhi-yong, G., 2007. $\mathrm{Pb}, \mathrm{Cu}, \mathrm{Zn}$ and $\mathrm{Ni}$ concentrations in vegetables in relation to their extractable fractions in soils in Suburban Areas of Nanjing, China. Polish Journal of Environmental Studies. 16 (2): 199-207.

10. Chen, M., Ma, L.Q., Harris, W.G., 1999. Baseline concentrations of 15 trace metals in Florida surface soils. Journal Environmental Quality 28:1173-1181.

11. Chinese Department of Preventive Medicine, 1995.Threshold for Food Hygiene. China Standard Press, Beijing.

12. Duruibe, J.O., Ogwuegbu, M.D.C., Egwurugwu, J.N., 2007. Heavy metal pollution and human biotoxic effects. International Journal of Physical. Sciences. 2 (5):112-118.

13. FAO/WHO 2001. Food additives and contaminants, Joint Codex Alimentarius Commission, FAO/WHO. Food standards Programme, ALINORM 01/12A.

14. Heike, B.B., 2004. Adsorption of heavy metal ions on soils and soils constituents. Journal of Colloid and Interface Science. 277: 1-18.

15. Kabata-Pendias, A., Pendias, H. 2000 Trace elements in soils and plants. $3^{\text {nd }}$ ed. CRC, USA.

16. Khan, S., Cao, Q., Zheng, Y. M., Huang, Y. Z., Zhu, Y. G. 2008. Health risks of heavy metals in contaminated soils and food crops irrigated with wastewater in Beijing, China. Environmental Pollution.152: 686-692.

17. Krishna, A.K., Govil, P.K., 2007. Soil contamination due to heavy metals from an idustrial area of Surat, Gujarat, Western India. Environmental monitoring and assessment. 124 (1-3): 263-275.

18. Mirsal, A. Ibrahim. 2004. Soil pollution origin, monitoring and remediation. Springer-Verlag, New York.

19. 19Modaihsh, A.S., Al Swailem, M.S., Mahjoub, M.D., 2004. Heavy metal content of commercial inorganic fertilizers used in the Kingdom of Saudi Arabia. Agricultural and Marine Sciences. 9: 21-25.

20. Nair, M., Balachandran, K.K., Sankarnarayan, V.N, Joseph, T. 1997. Heavy metals in fishes from coastal waters of Cochin, South West Coast of India. Indian Journal of Marine Science. 26: 98100.

21. Nicholson, F. A., Smith, S. R., Alloway, B. J., Carlton- Smith, C., Chambers, B. J. 2003. An inventory of heavy metals inputs to agricultural soils in England and Wales. Science of the Total Environment. 311: 205-219.

22. Schutzendubel, A., Schwanz, P., Teichmann, T., Gross, K., Langenfeld, "H.R.,Godbold, D.L., Polle, A., 2001. Cadmiuminduced change in antioxidative system, hydrogen peroxide content, and differentiation in scots pine roots. Plant Physiology.127: 887-898.

23. Sharma, R.K., Agrawal, M., Marshall, F.M. 2007. Heavy metals contamination of soil and vegetables in suburban areas of Varanasi, India. Ecotoxicology and Environmental Safety.66: 258-266

24. Sharma, R.K., Agrawal, M., Marshall,F.M. 2009.Heavy metals in vegetables collected from production and market sites of a tropical urban area of India. Food and Chemical Toxicology. 47: 583-591.

25. Singh, S., Kumar, M., 2006. Heavy metal load of soil, water and vegetables in periurban Delhi. Environmental Monitoring and Assessment. 120: 71-79.

26. Singh, A., Sharma, R.K., Agrawal, M., Marshall., 2010. Risk assessment of heavy metal toxicity through contaminated vegetables from waste water irrigated area of Varanasi, India. Tropical Ecology. 51(2S): 375-387. 
27. Singh, K.P., Mohon, D., Sinha, S., Dalwani, R. 2004. Impact assessment of treated/ untreated wastewater toxicants discharged by sewage treatment plants on health, agricultural, and environmental quality in wastewater disposal area. Chemosphere. 55: $227-255$.

28. Suciu, I., Cosma, C., Todica, M, Bolboaca, S. D., Jantschi, L. 2008. Analysis of soil heavy metal pollution and pattern in Central Transylvania. International Journal of Molecular Sciences. 9: 434-453.

29. Tijani, M.N., Onodera, S., 2009. Hydro-geochemical assessment of metals contamination in an urban drainage system: A case study of Osogbo Township, SW-Nigeria. International Journal of Water Resource and Protection. 3: 164-173.

30. Turekian, K.K., Wedepohl, K.H. 1961. Distribution of the elements in some major units of the earth's crust. Geological Society of America Bulletin. 72: 175-192.

31. Youssef, R.A., Chino, M., 1991.Movement of metals from soil to plant roots. Water air Soil Pollution.249: 57-58.

32. Zhang, C., 2006. Using multivariate analyses and GIS to identify pollutants and their spatial patterns in urban soils in Galway, Ireland. Environmental Pollution. 142: 501-511.

33. Zhang, L., Wong, M. H. 2007. Environmental mercury contamination in China: Sources and impacts. Environment International. 33: 108-121.

34. Zaidan, K.H., Terehi, M., Mamoori, A.M.J., Shuhaib, M.B., AlSaadi, A.H., Gathwan, K.H., 2013. Detection some trace elements in human milk and effect of some factors on its concentrations. Journal of Biology and Medical Sciences - JBMS. 1: 6-12. 